\title{
KELIMPAHAN DAN KEKAYAAN ARTROPODA PREDATOR PADA TANAMAN PADI YANG DIAPLIKASI BIOINSEKTISIDA BACILLUS THURINGIENSIS
}

\author{
Fila Sunariah $^{1}$, Siti Herlinda ${ }^{2,3}$, Chandra $\operatorname{Irsan}^{2,3}$, \& Yuanita Windusari ${ }^{4}$ \\ ${ }^{1}$ Program Studi Pengelolaan Lingkungan, Program Pascasarjana, Universitas Sriwijaya, Palembang \\ ${ }^{2}$ Jurusan Hama dan Penyakit Tumbuhan, Fakultas Pertanian, Universitas Sriwijaya, Indralaya \\ ${ }^{3}$ Pusat Unggulan Riset Pengembangan Lahan Suboptimal (PUR-PLSO), Universitas Sriwijaya Palembang \\ ${ }^{4}$ Program Studi Biologi, Fakultas Matematika dan Ilmu Pengetahuan Alam, Universitas Sriwijaya Palembang \\ E-mail: sitiherlinda@unsri.ac.id
}

\begin{abstract}
Abundance and species richness of the predatory arthropods on paddy treated with Bacillus thuringiensis bioinsecticide. Application of bioinsecticide from bacterial entomopathogen has not been reported yet that can decrease abundance and species richness of predatory arthropods, such as spiders and predatory insects. This research was aimed to analyze the abundance and species richness of predatory arthropods paddy fields applied by $B$. thuringiensis bioinsecticide on paddy in fresh swamp area. Areas observed were 2 ha paddy field's at Situ Bagendit variety. Predatory arthropods inhabiting canopy were sampled using sweep but soil dwelling arthropods were trapped using pitfall traps. The result showed that abundance of spiders inhabiting canopy decreased significantly after $B$. thuringiensis bioinsecticide application on paddy compared to control without bioinsecticide but the abundance of predatory insects were not significantly affected by the bioinsecticide. Application of the bioinsecticide did not significantly affect the abundance and species richness of soil dwelling predatory arthropods, such as spiders and predatory insects.
\end{abstract}

Key words: abundace, arthropod, paddy, species richness

\begin{abstract}
ABSTRAK
Kelimpahan dan kekayaan spesies artropoda predator pada tanaman padi yang diaplikasikan bioinsektisida Bacillus thuringiensis. Aplikasi bioinsektisida berbahan aktif bakteri belum banyak dilaporkan berdampak buruk terhadap kelimpahan dan keanekaragaman spesies artropoda predator, seperti laba-laba dan serangga predator. Penelitian ini bertujuan untuk menganalisis kelimpahan dan keanekaragaman spesies artropoda predator pada tanaman padi sawah lebak yang diaplikasikan bioinsektisida $B$. thuringiensis dan tanpa yang diaplikasikan bioinsektisida $B$. thuringiensis. Lahan yang diamati yaitu lahan padi sawah lebak yang ditanami varietas Situ Bagendit seluas 2 ha. Artropoda predator penghuni tajuk diamati menggunakan jaring serangga, sedangkan penghuni permukaan tanah menggunakan lubang jebakan. Dari hasil penelitian didapatkan bahwa kelimpahan laba-laba penguni tajuk menurun secara signifikan setelah aplikasi $B$. thuringiensis pada tanaman padi dibandingkan tanpa aplikasi (kontrol), namun untuk kelimpahan serangga predator penghuni tajuk tidak terpengaruh oleh aplikasi bioinsektisida tersebut. Aplikasi B. thuringiensis tidak berpengaruh nyata terhadap kekayaan spesies atropoda predator penghuni tanah, laba-laba dan serangga predator. Dengan demikian, aplikasi B. thuringiensis tidak menurunkan kelimpahan dan kekayaan spesies artropoda predator yang menghuni di permukaan tanah dan serangga predator tajuk.
\end{abstract}

Kata kunci: artropoda, kekayaan spesies, kelimpahan, padi

\section{PENDAHULUAN}

Ekosistem sawah telah banyak dilaporkan memiliki kelimpahan dan kekayaan spesies artropoda musuh alami yang tinggi (Herlinda et al., 2004; Wilyus et al., 2013; Herlinda et al., 2015b). Tingginya kekayaan spesies artropoda musuh alami dapat meningkatkan kestabilan ekosistem sehingga tidak didominasi oleh fitofag (Latoantja et al., 2013), namun banyak faktor yang dapat menyebabkan ketidakstabilan ekosistem sawah, misalnya aplikasi insektisida sintetik yang terbukti banyak menyebabkan kematian artropoda musuh alami (Herlinda et al., 2008; Udiarto et al., 2012), misalnya penurunan kelimpahan dan keanekaragaman spesies artropoda permukaan tanah dari Famili Lycosidae, Lyniphiidae, Carabidae, dan Formicidae pada ekosistem 
sawah akibat aplikasi deltametrin (Winasa \& Rauf, 2005).

Selain aplikasi insektisida sintetik, saat ini mulai banyak aplikasi bioinsektisida dilakukan untuk mengendalikan serangga hama, misalnya aplikasi jamur entomopatogen dari Beauveria bassiana (Herlinda, 2010; Hasyim, 2006) dan bakteri entomopatogen, seperti Bacillus thuringiensis (Uhan \& Sulastrini, 2008). B. thuringiensis telah banyak dilaporkan dapat mengendalikan serangga hama ordo Lepidoptera, seperti Crocidolomia pavonana (Uhan \& Sulastrini, 2008). Serangga hama lainnya yang dapat dikendalikan oleh B. thuringiensis adalah wereng coklat (Bernal et al., 2002), Rhopalosiphum padi (Raps et al., 2001), dan penggerek batang padi (Mulyaningsih et al., 2009). Dengan telah banyaknya informasi keefektifan $B$. thuringiensis untuk mengendalikan serangga hama padi, perlu juga informasi apakah aplikasi bakteri tersebut dapat menurunkan kelimpahan dan kekayaan spesies artropoda predator hama padi. Penelitian ini bertujuan untuk menganalisis kelimpahan dan kekayaan spesies artropoda predator pada tanaman padi yang diaplikasikan B. thuringiensis.

\section{METODE PENELITIAN}

Tempat dan Waktu. Penelitian ini dilaksanakan di lahan padi sawah lebak, Kecamatan Pemulutan, Kabupaten Ogan Ilir, Sumatera Selatan. Penelitian ini dimulai sejak bulan Mei hingga Agustus 2014.

Luas sawah yang diamati adalah 2 ha, setiap 1 ha dibagi menjadi 4 subpetak dengan ukuran $10 \times 10 \mathrm{~m}$. Varietas yang digunakan adalah varietas Situ Bagendit. Lahan tersebut dalam 1 ha dibagi menjadi 2 petak. Satu petak untuk lahan yang diberi bioinsektisida dan lahan lainnya sebagai kontrol.

Aplikasi Bioinsektisida. Bioinsektisida yang digunakan adalah $B$. thuringiensis $(\mathrm{Bt})$ yang berasal dari tanah rawa lebak dan telah diaplikasikan untuk pengendalian wereng coklat. Aplikasi bioinsektisida dilakukan dengan cara menyemprotkan $\mathrm{Bt}$ di tajuk tanaman padi utama dengan menggunakan alat knapsack sprayer. Bioinsektisida yang disemprotkan dengan dosis 2 1/ha setiap aplikasi. Aplikasi dilakukan sejak tanaman berumur 2 hingga 10 minggu setelah tanam (mst). Aplikasi dilakukan setiap 2 minggu sekali. Penyemprotan dilakukan pada sore hari pada pukul 16.00-18.00 WIB untuk mencegah bakteri terekspos oleh sinar terik matahari.
Pengamatan Artropoda Predator di Tajuk Tanaman Padi. Pengambilan sampel artropoda di tajuk tanaman padi dilakukan dengan menggunakan jaring serangga dan dilakukan sebanyak 15 ayunan dengan metode mengikuti Herlinda et al. (2015a). Setiap satu ayunan ganda artropoda yang tertangkap di jaring serangga dimasukkan ke kantong plastik yang telah berisi larutan $100 \mathrm{ml}$ formalin 2\%, begitu seterusnya sampai ayunan ke-15. Artropoda yang tertangkap selanjutnya dibawa ke laboratorium lalu disortasi dan dibersihkan dari formalin dengan menggunakan air, lalu dimasukkan ke dalam botol vial yang berisi alkohol $70 \%$. Identifikasi di bawah mikroskop dan dihitung jumlah individunya di Laboratorium Entomologi, Jurusan Hama dan Penyakit Tumbuhan, Fakultas Pertanian, Universitas Sriwijaya. Pengamatan artropoda di tajuk tanaman padi utama dilakukan setiap 2 minggu sekali dari umur 1 hingga 10 mst.

\section{Pengamatan Artropoda Predator pada Permukaan} Tanah Tanaman Padi. Pengambilan artropoda pada permukaan tanah menggunakan lubang jebakan (pitfall trap) mengikuti metode Effendy et al. (2013), yang dipasang sebanyak 12 perangkap per ha. Lubang jebakan dipasang setiap 2 minggu sekali berbarengan dengan jadwal pengambilan contoh serangga tajuk. Lubang perangkap dipasang selama $2 \times 24$ jam. Pemasangan perangkap dilakukan saat padi mulai berumur $1 \mathrm{mst}$ hingga 10 mst. Lubang jebakan (4 perangkap per subpetak) terbuat dari gelas plastik berdiameter $75 \mathrm{~mm}$, tinggi $100 \mathrm{~mm}$ dan bervolume $240 \mathrm{ml}$. Perangkap tersebut lalu diisi dengan larutan formalin $4 \%$ sebanyak sepertiga tinggi gelas plastik yang dipasang sejajar dengan permukaan tanah untuk memudahkan serangga terperangkap. Serangga predator yang tertangkap lubang jebakan disortasi, disaring dengan saringan ukuran pori $1 \mathrm{~mm}$, dibilas dengan air steril, lalu dimasukkan ked alam botol vial berisi alkohol $70 \%$, untuk selanjutnya diidentifikasi di bawah mikroskop dan dihitung jumlah individunya di Laboratorium Entomologi, Jurusan Hama dan Penyakit, Tumbuhan Fakultas Pertanian, Universitas Sriwijaya.

Analisis Data. Data komposisi spesies dan jumlah individu artropoda predator digunakan untuk menganalisis kelimpahan dan keanekaragaman spesies dan perbedaan antar perlakuan dianalisis menggunakan Chi Square. Ukuran keanekaragaman yang digunakan ialah indeks keanekaragaman Shannon Wiener, indeks dominasi spesies Berger-Parker, indeks kemerataan spesies Pielou dan indeks kemiripan Sorensen. 


\section{HASIL DAN PEMBAHASAN}

Kelimpahan dan Jumlah Spesies Artropoda Predator. Kelimpahan atau jumlah individu laba-laba penghuni tajuk menurun secara signifikan setelah aplikasi B. thuringiensis pada tanaman padi dibandingkan tanpa aplikasi (kontrol), namun untuk kelimpahan serangga predator penghuni tajuk tidak terpengaruh oleh aplikasi bioinsektisida tersebut. Jumlah spesies atau kekayaan spesies serangga predator penghuni tajuk cenderung tidak dipengaruh aplikasi $B$. thuringiensis. Kelimpahan dan jumlah spesies serangga netral turun secara signifikan (Tabel 1).

Tabel 1. Jumlah spesies dan jumlah individu (ekor/60 ayunan) (ekor/60 ayunan) artropoda tajuk di lahan padi yang diaplikasikan bioinsektisida dan tanpa diaplikasikan bioinsektisida

\begin{tabular}{|c|c|c|c|c|c|c|c|c|}
\hline Famili & JS A & JS B & Chi Square & P Value & JI A & JI B & Chi Square & $P$ Value \\
\hline \multicolumn{9}{|l|}{ Kelas Arachnida } \\
\hline Araneidae & 4 & 4 & $0,00^{\operatorname{tn}}$ & 1,00 & 12 & 19 & $1,58^{\mathrm{tn}}$ & 0,21 \\
\hline Lycosidae & 11 & 10 & $0,04^{\mathrm{tn}}$ & 0,82 & 22 & 22 & $0,00^{\operatorname{tn}}$ & 1,00 \\
\hline Tetragnathidae & 15 & 15 & $0,00^{\operatorname{tn}}$ & 1,00 & 314 & 366 & $3,98^{\mathrm{tn}}$ & 0,46 \\
\hline Lyniphiidae & 12 & 14 & $0,15^{\mathrm{tn}}$ & 0,69 & 63 & 84 & $3,00^{\operatorname{tn}}$ & 0,08 \\
\hline Oxyopidae & 10 & 9 & $0,05^{\mathrm{tn}}$ & 0,81 & 47 & 35 & $1,76^{\mathrm{tn}}$ & 0,19 \\
\hline Salticidae & 2 & 2 & $0,00^{\operatorname{tn}}$ & 1,00 & 2 & 2 & $0,00^{\operatorname{tn}}$ & 1,00 \\
\hline Jumlah & 54 & 54 & $0,00^{\operatorname{tn}}$ & 1,00 & 460 & 528 & $4,68^{*}$ & 0,03 \\
\hline \multicolumn{9}{|l|}{ Serangga Predator } \\
\hline \multicolumn{9}{|l|}{ COLEOPTERA } \\
\hline Carabidae & 3 & 4 & $0,14^{\mathrm{tn}}$ & 0,70 & 4 & 4 & $0,00^{\operatorname{tn}}$ & 1,00 \\
\hline Staphylinidae & 5 & 5 & $0,00^{\operatorname{tn}}$ & 1,00 & 29 & 35 & $0,56^{\mathrm{tn}}$ & 0,45 \\
\hline Coccinellidae & 8 & 7 & $0,06^{\mathrm{tn}}$ & 0,79 & 51 & 56 & $0,23^{\text {tn }}$ & 0,63 \\
\hline Crysomicidae & 3 & 4 & $0,14^{\mathrm{tn}}$ & 0,70 & 3 & 4 & $0,14^{\mathrm{tn}}$ & 0,70 \\
\hline \multicolumn{9}{|l|}{ ODONATA } \\
\hline Coenagrionidae & 5 & 5 & $0,00^{\operatorname{tn}}$ & 1,00 & 34 & 42 & $0,84^{\mathrm{tn}}$ & 0,36 \\
\hline Libellulidae & 3 & 2 & $0,20^{\mathrm{tn}}$ & 0,65 & 3 & 2 & $0,20^{\text {tn }}$ & 0,65 \\
\hline \multicolumn{9}{|l|}{ MANTODAE } \\
\hline Mantidae & 0 & 1 & $1,00^{\operatorname{tn}}$ & 0,31 & 0 & 1 & $1,00^{\operatorname{tn}}$ & 0,32 \\
\hline \multicolumn{9}{|l|}{ ORTHOPTERA } \\
\hline Tettigonidae & 5 & 5 & $0,00^{\operatorname{tn}}$ & 1,00 & 28 & 31 & $0,15^{\mathrm{tn}}$ & 0,70 \\
\hline Gryllidae & 10 & 10 & $0,00^{\operatorname{tn}}$ & 1,00 & 23 & 30 & $0,92^{\text {tn }}$ & 0,34 \\
\hline \multicolumn{9}{|l|}{ HEMIPTERA } \\
\hline Pentatomidae & 3 & 4 & $0,14^{\mathrm{tn}}$ & 0,70 & 4 & 4 & $0,00^{\mathrm{tn}}$ & 1,00 \\
\hline Jumlah & 45 & 47 & $0,04^{\mathrm{tn}}$ & 0,83 & 179 & 209 & $2,31^{\mathrm{tn}}$ & 0,12 \\
\hline \multicolumn{9}{|l|}{ Serangga hama } \\
\hline Delphacidae & 8 & 9 & $0,05^{\mathrm{tn}}$ & 0,80 & 13 & 28 & $5,49^{*}$ & 0,02 \\
\hline Cicadellidae & 12 & 15 & $0,33^{\text {tn }}$ & 0,56 & 47 & 61 & $1,81^{\text {tn }}$ & 0,18 \\
\hline \multicolumn{9}{|l|}{ HEMIPTERA } \\
\hline Alydidae & 3 & 3 & $0,00^{\operatorname{tn}}$ & 1,00 & 14 & 16 & $0,13^{\operatorname{tn}}$ & 0,72 \\
\hline Pentatomidae & 4 & 4 & $0,00^{\operatorname{tn}}$ & 1,00 & 5 & 4 & $0,11^{\mathrm{tn}}$ & 0,74 \\
\hline \multicolumn{9}{|l|}{ LEPIDOPTERA } \\
\hline Pyralidae & 5 & 4 & $0,11^{\mathrm{tn}}$ & 0,73 & 6 & 4 & $0,40^{\mathrm{tn}}$ & 0,53 \\
\hline Jumlah & 32 & 35 & $0,13^{\text {tn }}$ & 0,71 & 85 & 113 & $3,95^{*}$ & 0,04 \\
\hline \multicolumn{9}{|l|}{ Serangga Netral } \\
\hline \multicolumn{9}{|l|}{ HYMENOPTERA } \\
\hline Formicidae & 1 & 4 & $1,80^{\operatorname{tn}}$ & 0,17 & 1 & 5 & $2,67^{\mathrm{tn}}$ & 0,10 \\
\hline \multicolumn{9}{|l|}{ DIPTERA } \\
\hline Muscidae & 2 & 2 & $0,00^{\operatorname{tn}}$ & 1,00 & 2 & 0 & $2,00^{\operatorname{tn}}$ & 0,15 \\
\hline Serangga Lainnya & 5 & 5 & $0,00^{\mathrm{tn}}$ & 1,00 & 35 & 45 & $1,25^{\mathrm{tn}}$ & 0,26 \\
\hline Jumlah & 8 & 11 & $0,47^{\mathrm{tn}}$ & 0,49 & 38 & 50 & $1,63^{\mathrm{tn}}$ & 0,2 \\
\hline TOTAL & 139 & 147 & $0,22^{\text {tn }}$ & 0,63 & 762 & 900 & $11,45^{*}$ & 0,0007 \\
\hline
\end{tabular}

JS A: Jumlah spesies pada aplikasi bioinsektisida; JS B: Jumah spesies pada kontrol; JI A: Jumlah individu pada aplikasi bioinsektisida; JI B: Jumlah individu pada kontrol; Angka yang diikuti tanda * pada baris yang sama menunjukkan nilai berbeda nyata pada uji chi square 5\%; tn: tidak berbeda nyata pada uji chi square 5\%. 
Total populasi serangga hama turun secara signifikan dari 113 ekor/60 ayunan menjadi 85 ekor/60 ayunan setelah diaplikasikan $B$. thuringiensis (Tabel 1). Penurunan total populasi serangga hama diikuti dengan penurunan kelimpahan predatornya, yaitu labalaba dari 528 ekor/60 ayunan menjadi 460 ekor/60 ayunan. Penurunan kelimpahan laba-laba ini disebabkan oleh penurunan populasi serangga hama tersebut sebagai mangsanya. Nelly et al. (2012) dan Aswad et al. (2014) menyatakan fluktuasi kerapatan predator yang baik cenderung mengikuti fluktuasi mangsanya. Lebih khusus lagi hasil riset Munyuli (2009) menemukan kelimpahan Lycosidae cenderung akan mengikuti fluktuasi wereng yang merupakan mangsanya. Pada penelitian ini, labalaba penghuni tajuk dan laba-laba pemburu berfluktuasi mengikuti fluktuasi mangsanya. Laba-laba cenderung berperan sebagai predator yang baik bila mengikuti pola fluktuasi mangsanya. Widiarta et al. (2006) menyatakan perilaku laba-laba akan mengumpul pada habitat yang mangsanya berlimpah. Arofah et al. (2013) menambahkan bahwa mangsa laba-laba adalah serangga hama padi, seperti wereng dan penggerek batang.

Aplikasi B. thuringiensis tidak berpengaruh nyata terhadap jumlah spesies atau kekayaan spesies atropoda predator penghuni tanah, baik laba-laba maupun serangga predator. Aplikasi B. thuringiensis juga tidak berdampak terhadap penurunan populasi serangga netral dan serangga hama (Tabel 2). Serangga hama yang ditemukan di permukaan tanah adalah kelompok jangkrik dan orong-orong. Dengan demikian, serangga hama yang ada di permukaan tanah tidak efektif bila diaplikasi oleh B. thuringiensis karena tidak berdampak terhadap penurunan populasinya. Dari fenomena ini tampak bahwa kelimpahan dan kekayaan spesies predator penghuni permukaan tanah tidak terpengaruh oleh aplikasi $B$. thuringiensis sehingga relatif aman untuk kehidupan predator permukaan tanah. Chen et al. (2006) melaporkan bahwa aplikasi tanaman yang mengandung B. thuringiensis tidak mempengaruhi secara nyata

Tabel 2. Jumlah spesies dan jumlah individu (ekor/60 ayunan) artropoda tanah di lahan padi yang diaplikasikan bioinsektisida dan tanpa diaplikasikan bioinsektisida

\begin{tabular}{|c|c|c|c|c|c|c|c|c|}
\hline Famili & JSA & JSB & $\begin{array}{c}\text { Chi } \\
\text { Square }\end{array}$ & $P$ Value & JIA & JIB & $\begin{array}{c}\text { Chi } \\
\text { Square }\end{array}$ & $P$ Value \\
\hline \multicolumn{9}{|l|}{ Arachnida } \\
\hline $\begin{array}{l}\text { Lyniphiidae } \\
\text { Salticidae } \\
\text { Jumlah }\end{array}$ & $\begin{array}{c}2 \\
1 \\
17\end{array}$ & $\begin{array}{c}2 \\
0 \\
17\end{array}$ & $\begin{array}{l}0,00^{\text {tn }} \\
1,00^{\text {tn }} \\
0,00^{\text {tn }}\end{array}$ & $\begin{array}{l}1,00 \\
0,31 \\
1,00\end{array}$ & $\begin{array}{c}2 \\
1 \\
57\end{array}$ & $\begin{array}{c}2 \\
0 \\
62\end{array}$ & $\begin{array}{l}0,00^{\text {tn }} \\
1,00^{\text {tn }} \\
0,21^{\text {tn }}\end{array}$ & $\begin{array}{l}1,00 \\
0,32 \\
0,64\end{array}$ \\
\hline \multicolumn{9}{|c|}{ Serangga Predator } \\
\hline $\begin{array}{l}\text { Carabidae } \\
\text { Staphylinidae } \\
\text { Coccinellidae }\end{array}$ & $\begin{array}{c}15 \\
5 \\
1\end{array}$ & $\begin{array}{c}14 \\
6 \\
4\end{array}$ & $\begin{array}{l}0,03^{\text {tn }} \\
0,09^{\text {tn }} \\
1.80^{\text {tn }}\end{array}$ & $\begin{array}{l}0,82 \\
0,76 \\
0,17\end{array}$ & $\begin{array}{c}81 \\
8 \\
1\end{array}$ & $\begin{array}{c}88 \\
7 \\
5\end{array}$ & $\begin{array}{l}0,29^{\text {tn }} \\
0,07^{\text {tn }} \\
2.67^{\text {tn }}\end{array}$ & $\begin{array}{l}0,59 \\
0,80 \\
0,10\end{array}$ \\
\hline \multicolumn{9}{|l|}{ Orthoptera } \\
\hline Gryllidae & 2 & 4 & $0,66^{\mathrm{tn}}$ & 0,41 & 2 & 6 & $2,00^{\operatorname{tn}}$ & 0,16 \\
\hline Jumlah & 23 & 28 & $0,49^{\mathrm{tn}}$ & 0,48 & 92 & 106 & $0,98^{\mathrm{tn}}$ & 0,31 \\
\hline \multicolumn{9}{|l|}{ Serangga Hama } \\
\hline Gryllotalpidae & 5 & 5 & $0,00^{\text {tn }}$ & 1,00 & 18 & 22 & $0,40^{\operatorname{tn}}$ & 0,52 \\
\hline Jumlah & 5 & 5 & $0,00^{\text {tn }}$ & 1,00 & 18 & 22 & $0,40^{\operatorname{tn}}$ & 0,52 \\
\hline \multicolumn{9}{|c|}{ Serangga Netral } \\
\hline Formicidae & 13 & 17 & $0,53^{\text {tn }}$ & 0,46 & 67 & 87 & $2,60^{\text {tn }}$ & 0,11 \\
\hline Jumlah & 13 & 17 & $0,53^{\text {tn }}$ & 0,46 & 67 & 87 & $2,60^{\operatorname{tn}}$ & 0,11 \\
\hline TOTAL & 58 & 117 & $5,80^{*}$ & 0,016 & 401 & 467 & $5,01^{*}$ & 0,02 \\
\hline
\end{tabular}

JSA: Jumlah spesies pada aplikasi bioinsektisida, JSB: Jumah spesies pada kontrol; JIA: Jumlah individu pada aplikasi bioinsektisida; JIB: Jumlah individu pada kontrol; Angka yang diikuti tanda * pada baris yang sama menunjukkan nilai berbeda nyata pada uji chi square 5\%; tn: tidak berbeda nyata pada uji chi square $5 \%$. 
terhadap artropoda bukan sasaran seperti serangga predator. B. thuringiensis cenderung spesifik menyerang serangga hama dari Ordo Lepidoptera.

Pada penelitian di sawah lebak ini apabila data kelimpahan artropoda predator tajuk dibandingkan dengan artropoda predator tanah (Tabel 1 dan 2), maka ada temuan yang menarik berupa dominasi famili tertentu pada masing-masing habitat tersebut. Pada laba-laba penghuni tajuk didominasi oleh Tetragnathidae, sedangkan serangga predator penghuni tajuk didominasi oleh Coccinellidae. Hasil ini sejalan dengan hasil penelitian Khodijah (2014) di sawah pasang surut. Pada penelitian ini, laba-laba penghuni permukaan tanah sawah lebak didominasi oleh Lycosidae, sedangkan serangga predator permukaan tanah didominasi oleh Carabidae. Dominasi Lycosidae dan Carabidae ini dilaporkan juga oleh Khodijah et al. (2012) dan Herlinda et al. (2014) di permukaan tanah sawah daerah pasang surut.

Karakteristik Komunitas Artropoda Predator. Pada pengamatan setiap dua minggu sekali, jumlah individu predator penghuni tajuk cenderung mengalami penurunan setelah aplikasi B. thuringiensis (Tabel 3), sedangkan pada predator penghuni tanah tidak menunjukkan kecenderungan adanya penurunan kelimpahan predatornya (Tabel 4). Keanekaragaman spesies artropoda predator baik penghuni tajuk dan tanah cenderung tidak menurun setelah diaplikasi $B$. thuringiensis. Penurunan predator penghuni tajuk pada penelitian ini bukan karena terbunuh oleh $B$. thuringiensis tetapi disebabkan oleh menurunnya populasi mangsa pada Tabel 1. Raps et al. (2001) dan Mulyaningsih et al. (2009) menyatakan B. thuringiensis tidak membunuh serangga dan artropoda bukan sasaran, seperti artropoda predator.

Komposisi Kelompok Artropoda. Komposisi artropoda yang ditemukan pada tajuk padi sawah lebak terdiri dari laba-laba, serangga predator, serangga hama, dan serangga netral, untuk parasitoid tidak diamati pada penelitian ini. Komposisi artropoda penghuni tajuk di lahan padi yang diaplikasikan bioinsektisida menunjukkan persebaran berdasarkan komposisi artropoda, yaitu labalaba $60 \%$, serangga predator $24 \%$, serangga hama $11 \%$, dan serangga netral $5 \%$. Untuk total jumlah artropoda

Tabel 3. Karakteristik komunitas artropoda predator yang aktif di tajuk tanaman padi yang diaplikasikan bioinsektisida dan tanpa diaplikasikan bioinsektisida

\begin{tabular}{|c|c|c|c|}
\hline Umur tanaman (mst) & Karakteristik Komunitas & Bioinsektisida (Bt) & Kontrol \\
\hline \multirow{4}{*}{2} & Jumlah Individu (N) & 89,00 & 108,00 \\
\hline & Indeks Keanekaragaman $\left(\mathrm{H}^{\prime}\right)$ & 1,98 & 1,80 \\
\hline & Indeks Dominasi (d) & 0,39 & 0,49 \\
\hline & Indeks Kemerataan (E) & 0,80 & 0,73 \\
\hline \multirow{4}{*}{4} & Jumlah Individu (N) & 147,00 & 151,00 \\
\hline & Indeks Keanekaragaman $\left(\mathrm{H}^{\prime}\right)$ & 1,57 & 1,71 \\
\hline & Indeks Dominasi (d) & 0,59 & 0,58 \\
\hline & Indeks Kemerataan (E) & 0,63 & 0,67 \\
\hline \multirow{4}{*}{6} & Jumlah Individu (N) & 124,00 & 147,00 \\
\hline & Indeks Keanekaragaman $\left(\mathrm{H}^{\prime}\right)$ & 1,74 & 2,04 \\
\hline & Indeks Dominasi (d) & 0,56 & 0,50 \\
\hline & Indeks Kemerataan (E) & 0,76 & 0,80 \\
\hline \multirow{4}{*}{8} & Jumlah Individu (N) & 120,00 & 156,00 \\
\hline & Indeks Keanekaragaman $\left(\mathrm{H}^{\prime}\right)$ & 2,05 & 2,09 \\
\hline & Indeks Dominasi (d) & 0,45 & 0,46 \\
\hline & Indeks Kemerataan (E) & 0,78 & 0,79 \\
\hline \multirow{4}{*}{10} & Jumlah Individu (N) & 161,00 & 179,00 \\
\hline & Indeks Keanekaragaman $\left(\mathrm{H}^{\prime}\right)$ & 2,23 & 2,15 \\
\hline & Indeks Dominasi (d) & 0,42 & 0,44 \\
\hline & Indeks Kemerataan (E) & 0,85 & 0,81 \\
\hline \multirow{4}{*}{ Rata-rata } & Jumlah Individu (N) & 128,00 & 148,00 \\
\hline & Indeks Keanekaragaman $\left(\mathrm{H}^{\prime}\right)$ & 1,91 & 1,96 \\
\hline & Indeks Dominasi (d) & 0,48 & 0,49 \\
\hline & Indeks Kemerataan (E) & 0,76 & 0,76 \\
\hline
\end{tabular}


predator penghuni tajuk menempati $84 \%$ lahan padi yang diaplikasikan $B$. thuringiensis, sedangkan pada lahan yang tidak diaplikasikan total jumlah artropoda predator (laba-laba dan serangga predator) adalah 81\% (Gambar
1). Untuk artropoda penghuni permukaan tanah jelas didominasi oleh laba-laba dan serangga predator, baik pada petak yang diaplikasi $B$. thuringiensis maupun petak kontrol (Gambar 2). Pada penelitian ini jelas

Tabel 4. Karakteristik komunitas artropoda predator yang aktif di tanah tanaman padi yang diaplikasikan bioinsektisida dan tanpa diaplikasikan bioinsektisida

\begin{tabular}{clrr}
\hline Umur tanaman (mst) & Karakteristik Komunitas & Bioinsektisida (Bt) & Kontrol \\
\hline \multirow{4}{*}{2} & Jumlah Individu (N) & 33,00 & 26,00 \\
& Indeks Keanekaragaman (H') & 2,21 & 1,04 \\
& Indeks Dominasi (d) & 0,61 & 0,50 \\
& Indeks Kemerataan (E) & 1,37 & 0,75 \\
\hline \multirow{4}{*}{4} & Jumlah Individu (N) & 30,00 & 44,00 \\
& Indeks Keanekaragaman (H') & 0,69 & 1,67 \\
& Indeks Dominasi (d) & 0,53 & 0,98 \\
& Indeks Kemerataan (E) & 1,00 & 0,93 \\
\hline \multirow{4}{*}{6} & Jumlah Individu (N) & 33,00 & 30,00 \\
& Indeks Keanekaragaman (H') & 0,88 & 1,05 \\
& Indeks Dominasi (d) & 0,61 & 0,70 \\
& Indeks Kemerataan (E) & 0,64 & 0,76 \\
\hline \multirow{2}{*}{8} & Jumlah Individu (N) & 26,00 & 29,00 \\
& Indeks Keanekaragaman (H') & 1,41 & 0,94 \\
& Indeks Dominasi (d) & 0,52 & 0,52 \\
& Indeks Kemerataan (E) & 0,87 & 0,68 \\
\hline \multirow{3}{*}{10} & Jumlah Individu (N) & 27,00 & 39,00 \\
& Indeks Keanekaragaman (H') & 1,26 & 1,61 \\
& Indeks Dominasi (d) & 0,44 & 0,46 \\
& Indeks Kemerataan (E) & 0,91 & 0,90 \\
\hline \multirow{2}{*}{ Rata-rata } & Jumlah Individu (N) & 30,00 & 34,00 \\
& Indeks Keanekaragaman (H') & 1,29 & 1,26 \\
& Indeks Dominasi (d) & 0,54 & 0,63 \\
& Indeks Kemerataan (E) & 0,96 & 0,80 \\
\hline
\end{tabular}

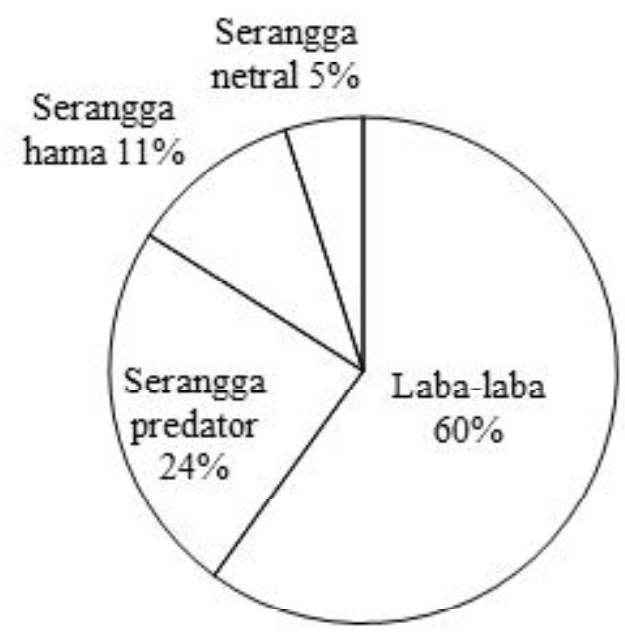

A

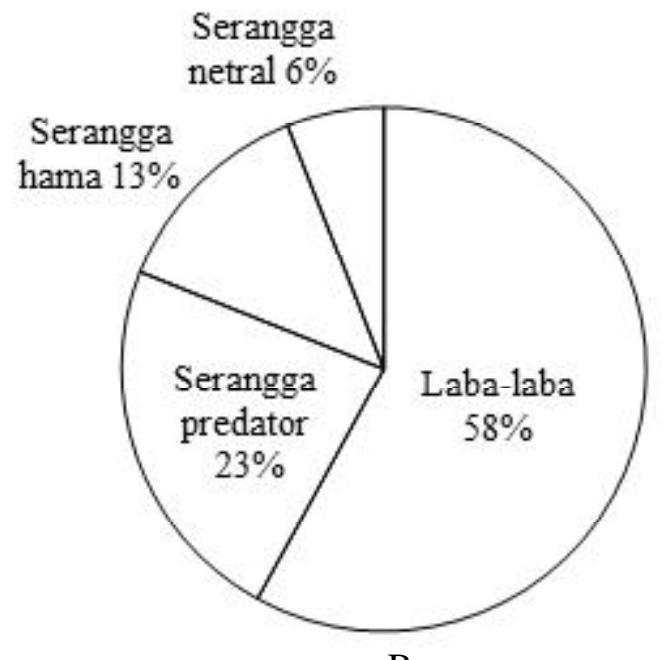

B

Gambar 1. Komposisi artropoda tajuk di lahan padi berdasarkan tingkat tropik umur 2-10 minggu setelah tanam (mst) (A) diaplikasikan bioinsektisida (B) tanpa diaplikasikan bioinsektisida 


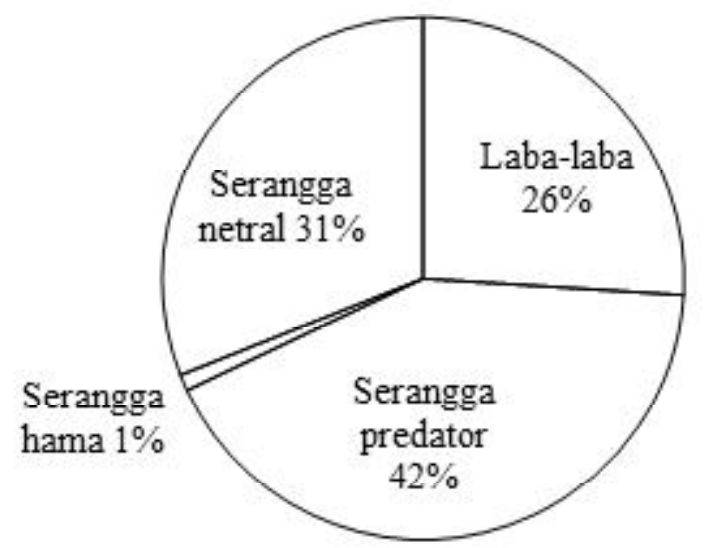

A

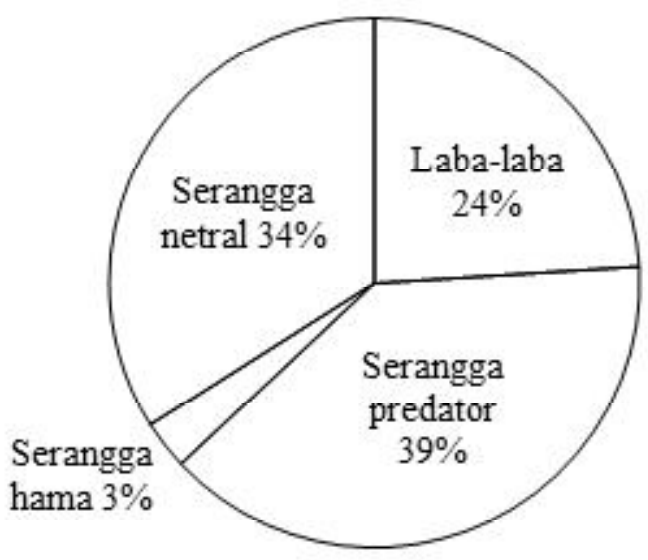

$\mathrm{B}$

Gambar 2. Komposisi artropoda tanah di lahan padi berdasarkan tingkat tropik umur 2-10 minggu setelah tanam (A) diaplikasikan bioinsektisida (B) tanpa diaplikasikan bioinsektisida

memperlihatkan bahwa aplikasi $B$. thuringiensis tidak menyebabkan dominasi serangga hama tapi tetap didominasi oleh kelompok predator. Herlinda et al. (2004) menemukan fenomena yang sejalan dengan hasil riset ini, yaitu pada lahan tanaman padi sawah irigasi juga didominasi oleh artropoda predator, baik laba-laba maupun serangga predator. B. thuringiensis menurut Senewe et al. (2013) efektif membunuh serangga hama spesifik seperti kelompok Lepidoptera dan tidak membahayakan artropoda bukan sasaran.

\section{SIMPULAN}

Kelimpahan laba-laba penguni tajuk menurun secara signifikan setelah aplikasi $B$. thuringiensis pada tanaman padi dibandingkan tanpa aplikasi (kontrol), namun untuk kelimpahan serangga predator penghuni tajuk tidak terpengaruh oleh aplikasi bioinsektisida tersebut. Aplikasi B. thuringiensis tidak berpengaruh nyata terhadap kekayaan spesies atropoda predator penghuni tanah, laba-laba dan serangga predator. Dengan demikian, aplikasi B. thuringiensis tidak menurunkan kelimpahan dan kekayaan spesies artropoda predator yang menghuni di permukaan tanah dan serangga predator tajuk.

\section{SANWACANA}

Penelitian ini dibiayai oleh Program IbM, DP2M, Ditjen Dikti, Kemendikbud Tahun Anggaran 2014 a.n Siti Herlinda untuk itu kami mengucapkan terima kasih kepada DP2M, Ditjen Dikti, Kemendikbud.

\section{DAFTAR PUSTAKA}

Arofah S, Trisnawati I, \& Tjahjaningrum D. 2013. Pengaruh habitat termodifikasi menggunakan serai terhadap serangga herbivora dan produktivitas padi varietas IR-64 di Desa Purwosari, Pasuruan. J. Sains dan Seni Pomits 2(2): 2337-3520.

Aswad M, Koneri R, Saroyo, \& Siahaan P. 2014. Komunitas laba-laba (Arachnida: Araneae) pada lahan perkebunan di kawasan Taman Nasional Bogani Nani Wartabone Sulawesi Utara. J. Mipa Unsrat 3(2): 64-67.

Bernal CC, Aguda RM, \& Cohen MB. 2002. Effect of rice lines transformed with Bacillus thuringiensis toxin genes on the brown planthopper and its predator Cyrtorhinus lividipennis. Entomol. Exp. Appl. 102: 21-28.

Chen M, Ye GY, Liu ZC, Yao HW, Chen XX, Shen ZC, Hu C, \& Datta SK. 2006. Field assessment of the effects of transgenic rice expressing a fused gene of $c r y l A b$ and $c r y l A c$ from Bacillus thuringiensis Berliner on nontarget planthopper and leafhopper populations. Environ. Entomol. 35(1): 127-134.

Effendy, Hety U, Herlinda S, Irsan C, \& Thalib R. 2013. Analisis kemiripan komunitas artropoda predator hama padi penghuni permukaan tanah sawah rawa lebak dengan lahan pinggir di sekitarnya. $J$. Entomol. Indones. 10(2): 60-68. 
Hasyim A. 2006. Evaluasi bahan carrier dalam pemanfaatan jamur entomopatogen, Beauveria bassiana (Balsamo) Vuillemin untuk mengendalikan hama penggerek bonggol pisang, Cosmopolites sordidus GERMAR. J. Hort. 16(3): 202-210.

Herlinda S. 2010. Spore density and viability of entomopathogenic fungal isolates from Indonesia, and their virulence against Aphis gossypii Glover (Homoptera: Aphididae). Trop. Life Sci. Res. 21(1): 11-19.

Herlinda S, Dewi R, Adam T, Suwandi, \& Wijaya A. 2015a. Struktur komunitas laba-laba di ekosistem padi ratun: pengaruh aplikasi Beauveria bassiana (Balsamo). J. Entomol. Indones. 12(2): 91-99.

Herlinda, Kusuma A, Suwandi, \& Wijaya A. 2015 b. Perbandingan efek pemberian bioinsektisida dan ekstrak kompos terhadap produksi padi ratun dan populasi serangga hama. J. Agron. Indones. 43(1): 23-28.

Herlinda S, Manalu HCN, Aldina RF, Suwandi, Wijaya A, Khodijah, \& Meidalima D. 2014. Kelimpahan dan keanekaragaman spesies laba-laba predator hama padi ratun di sawah pasang surut. J. HPT Tropika 14(1): 1-7.

Herlinda S, Rauf A, Sosromarsono S, Kartosuwondo U, Siswadi, \& Hidayat P. 2004. Artropoda predator penghuni ekosistem persawahan di daerah Cianjur, Jawa Barat. J. Entomol. Indones. 1(1): 9-15.

Herlinda S, Rauf A, Sosromarsono S, Kartosuwondo U, Siswadi, \& Hidayat P. 2004. Artropoda musuh alami penghuni ekosistem persawahan di daerah Cianjur, Jawa Barat. J. Entomol. Indones. 1(1): 9-15.

Herlinda S, Waluyo, Estuningsih SP, \& Irsan C. 2008. Perbandingan keanekaragaman spesies dan kelimpahan arthropoda predator penghuni tanah di sawah lebak yang diaplikasi dan tanpa diaplikasi insektisida. J. Entomol. Indones. 5(2): 96-107.

Khodijah, Herlinda S, Irsan C, Pujiastuti Y, \& Thalib R. 2012. Artropoda predator penghuni ekosistem persawahan lebak dan pasang surut Sumatera Selatan. J. Lahan Suboptimal 1(1): 57-63.

Khodijah. 2014. Kelimpahan relatif laba-laba predator di tajuk tanaman padi yang diaplikasikan bioinsektisida di daerah pasang surut. J. Ilmiah AgrIBA 2(1): 122-129.
Latoantja AS, Hasriyanti, \& Anshary A. 2013. Inventarisasi artropoda pada permukaan tanah di pertanaman cabai (Capsicum annum L.). e-J. Agrotekbis 1(5): 406-412.

Mulyaningsih ES, Deswina P, \& Slamet-Loedin IH. 2009. Dampak padi transgenik mengekspresikan gen CrylA(b) untuk ketahanan terhadap penggerek batang di lapangan terbatas tehadap serangga bukan sasaran. J. HPT Tropika 9(2): 85-91.

Munyuli T. 2009. Is Pardosa pseudoannulata an effective predator agent of Aphis craccivora in Uganda and in Democratic Republic of Congo? Tunisian J. Plant Protect. 4(1): 91-98.

Nelly N, Trizelia, \& Syuhadah Q. 2012. Tanggap fungsional Menochilus sexmaculatus Fabricius (Coleoptera: Coccinellidae) terhadap Aphis gossypii (Glover) (Homoptera: Aphididae) pada umur tanaman cabai berbeda. J. Entomol. Indones. 9(1): 23-31.

Nunilahwati N, Herlinda S, Irsan C, \& Pujiastuti Y. 2012. Eksplorasi, isolasi, dan seleksi jamur Entomopatogen Plutella xylostella (Lepidoptera: Yronomeutidae) pada pertanaman caisin Brassica chinensis di Sumatera Selatan. J. HPT Tropika 12(1): 1-11.

Raps A, Kehr J, Gugerli P, Moar WJ, \& Bigler F \& Hilbeck A. 2001. Immunological analysis of phloem sap of Bacillus thuringiensis corn and of the nontarget herbivore Rhopalosiphum padi (Homoptera: Aphididae) for the presence of Cry1Ab. Mol. Ecol. 10(2): 525-533.

Senewe RE, Wagiman FX, \& Wiryadiputra S. 2013. Tingkat keefektifan formulasi bioinsektisida Bacillus thuringiensis terhadap hama penggerek buah kakao pada kondisi di lapangan. Pelita Perkebunan 29(2): 108-119.

Udiarto BK, Hidayat P, Rauf A, Pudjianto, \& Hidayat SH. 2012. Kajian potensi predator Coccinellidae untuk pengendalian Bemisia tabaci (Gennadius) pada cabai merah. J. Hort. 22(1): 76-84.

Uhan TS \& Sulastrini I. 2008. Efektivitas aplikasi kombinasi Steinernema carpocapsae dan biopestisida Bacillus thuringiensis terhadap mortalitas Crocidolomia pavonana $\mathrm{F}$ pada tanaman kubis di rumah kaca. J. Hort. 18(1):3845 . 
Widiarta IN, Kusdiaman D, \& Suprihanto. 2006. Keragaman arthropoda pada padi sawah dengan pengelolaan tanaman terpadu. J. HPT Tropika 6(2): 61-69.

Wilyus, Nurdiansyah F, Johari A, Herlinda S, \& Pujiastuti Y. 2013. Keanekaragaman, dominasi, persebaran spesies penggerek batang padi dan serangannya pada berbagai tipologi lahan di Provinsi Jambi. $J$. HPT Tropika 13(1): 87-95.
Winasa IW \& Rauf A. 2005. Pengaruh sampling aplikasi deltramin terhadap artropoda predator penghuni permukaan tanah di pertanaman kedelai. $J$. Entomol. Indones. 2(1): 39-47. 